\title{
A Needs Analysis for English Speaking Syllabus Development
}

\author{
Dewi Yana \\ English Education Department \\ University of Riau Kepulauan \\ alifdewi@yahoo.com
}

\begin{abstract}
This study aims at identifying the students' needs in learning English speaking to promote speaking syllabus development. This research was a qualitative descriptive research. The subjects were 63 students of the first, third and fifth semester of English Education Study Program of Teacher Training and Education Faculty of Riau Kepulauan University. The data were collected using a questionnaire. The questioner is aimed at gathering information related to the target needs, and wants. The results found that the students target of studying English speaking are for their future profession and for their higher education. They want practicing the English speaking when they are studying, and they want enjoying a lot of speaking activities at the classroom together with their pair or group. They also want the speaking course exist as the English education study curriculum. The students assumed for the role of teacher as a facilitator and guide in the teaching learning activities.
\end{abstract}

Keywords : needs analysis, speaking syllabus development

\section{INTRODUCTION}

Speaking is one of the most important language skills in learning English. It is the skill which is taught as a language course at English Education Study Program of Teacher Training and Education Faculty of Riau Kepulauan University. The main goal is to enable the learners to speak in target language that is spoken in English communicatively. Unfortunately, making students speak communicatively is not a simple job for the lecturer to do. The Lecturer has to prepare a best way to teach them. One of the helpful ways is planning a syllabus based on the students needs. The teachers have to analyze the learners' needs before designing syllabus and before deciding an appropriate learning material and also the teaching learning strategy. Manalullaili explained that analyzing the learners needs will help the learners learn naturally related to their interest (Manalullaili, 2014). Toward need analysis the teacher can gather some information about particular language function which the students needed to learn 
of it such as their target, wants, and lacks in the teaching learning process. Therefore the teacher can determine the learning objective and design an appropriate speaking syllabus which covers a match learning material, suitable strategies, and valid evaluation. Finally, the syllabus designed based on the students needs is expected to make the students of English Speaking course are being able to speak communicatively.

\section{Need Analysis}

Need Analysis is a way to gather some information related to the learners' needs. It appeared firstly in 1920s at India and widespread as a research in language planning in the early of 1970s (Pusphanatahan 2013:2, Otilia 2015:54). It "represents a form of assessing particular linguistics needs of the trainee or group of them (Jeczelewski, 2016:10). It's also stated as an information gathering process (Pusphanatahan, 2013:2, Boroujeni \& Fard 2013:37). The function of Needs Analysis is to reduce any gap among learners, teachers, and teaching materials (Haque, 2014). Then, Otilia explained that needs analysis "consisted in assessing the communicative needs of the learners and the techniques of achieving specific teaching objectives" (Otilia,2015). Therefore it can be conclude that a language teacher or lecturer can apply needs analysis to get some information in planning the teaching learning process.

There are 3 steps can be applied by a language teacher or lecturer at doing needs analysis. They are planning, collecting data, and putting information into the analysis (Jeczelewiski 2016:10). The planning refers to the instrument writing. It covers some questions related to needs analysis components. Then, the questioner will be use to collect the data of the students needs. Finally the data in the form of information of the students need is analyzed as the consideration for designing a teaching syllabus.

Dickinson in Jeczelewisk. He defined "Needs are those skills which a learner perceives as being relevant to him; wants are a subset of needs, those which a learner puts at a high priority given the time available; and the lack is the difference a learner perceives between his present competence in a particular skill and the competence he wishes to achieve" (Dickinson, 1991 cited in Jeczeleweski, 2016:10).

\section{Speaking}


Speaking is one of basic skills to build a communication. It refers to a process of producing verbal words to transfer meaning to listener. The common speaking definition was proposed by Chaney as "the process of building and sharing meaning through the use of verbal and non-verbal symbols, in a variety of contexts" (Chaney cited in Kayi 2006 then cited in Solcova, 2011:17). While Torky defined speaking as the learner's ability to express himself or herself orally, coherently, fluently and appropriately in a given meaningful context. (Torky, 2006:34). At this perception he divided three aspects of speaking as a skill in English language teaching learning process. The aspects should be considered in planning a language course in order preparing the students speaks communicatively in real life situation. Those aspects are:

a. Speaking is face to face: at this aspect facial expression, gesture and body movement are valuable meaning..

b. Speaking is interactive: the conversation run smoothly between speaker and listener who participate with appropriate context and situation.

c. Speaking happens in real time: language interaction between speaker and listener at real time gives a chance to do self-correction, repetition among them. As the result it will allow them become more fluent and responsive to the real time demand.

\section{Syllabus}

Syllabus is a part of curriculum. It is a documented planning of teaching learning process encompasses of learning goal, learning materials, learning activities, teaching strategies and assessment. Then, it strengthens by Jeczelewiski who quoted the term of syllabus from Hyland as "a plan of what is to be achieved through teaching and learning, identifying what will be worked on in reaching the overall course aims and providing a basis for evaluating students' progress" (Hyland, 2006 in Jeczelewiski, 2016).

\section{METHODOLOGY}


This research is categorized into a qualitative research. The participants of this study were 63 of the first, third, and fifth semester students of English Education Study Program of Teacher Training and Education Faculty Riau Kepulauan University Academic Year 2016/2017. The data collection instrument was in the form of a questioner sheet. In the questionnaire, the learners were asked to answer several questions in relation to their target, want and their lacks of learning English Speaking by choosing one or more option from several options provided. However, they are also allowed to give other answers related to the questions. , the detailed questions were adapted from Boroujeni \& Fard, 2013:38). They are as follow:

1. the present and future domains of language use and thus reasons for studying English

2. The students' attitude towards the place and role of English in the school curriculum

3. Learning preferences in terms of language skills

4. The importance of particular language skills

5. Preferred learning styles and strategies

6. Patterns of learner to learner interaction

7. Role relationship

8. Preference for teaching activities

\section{RESULT}

The results of the needs analysis are presented in table 1-8 as follows:

Table 1. The reasons for studying English speaking

\begin{tabular}{|c|c|c|c|c|c|c|}
\hline NO & QUESTIONS & & OPTIONS OF THE ANSWER & $\mathbf{N}$ & $\begin{array}{c}\text { STUDENTS' } \\
\text { ANSWER }\end{array}$ & $\%$ \\
\hline \multirow[t]{5}{*}{1} & $\begin{array}{l}\text { Why do you need to } \\
\text { study English } \\
\text { speaking? }\end{array}$ & a. & To get higher education & 63 & 16 & 25.4 \\
\hline & & b. & $\begin{array}{l}\text { To get success for future } \\
\text { profession }\end{array}$ & 63 & 43 & 68.3 \\
\hline & & c. & To speak to foreigner & 63 & 1 & 1.6 \\
\hline & & $\mathrm{d}$. & To speak to friends and family & 63 & 0 & 0.0 \\
\hline & & e. & Other.... & 63 & 0 & 0.0 \\
\hline
\end{tabular}


Question number one was to know the students' reason of studying English speaking. Based on the data in Table 1 above, it can be seen that $25.4 \%$ of the students consider to get higher education; $68.3 \%$ consider to get success for future profession; and only $1.6 \%$ of them consider to speak to foreigner.

Table 2. Timing on studying English speaking

\begin{tabular}{|c|c|c|c|c|c|c|}
\hline NO & QUESTIONS & & OPTIONS OF THE ANSWER & $\mathbf{N}$ & $\begin{array}{c}\text { STUDENTS' } \\
\text { ANSWER }\end{array}$ & $\%$ \\
\hline \multirow[t]{5}{*}{2} & When do you use & a. & When studying & 63 & 46 & 73.0 \\
\hline & English speaking? & b. & When socializing & 63 & 9 & 14.3 \\
\hline & & c. & At home & 63 & 3 & 4.8 \\
\hline & & d. & At office & 63 & 5 & 7.9 \\
\hline & & e. & Other.... & 63 & 0 & 0.0 \\
\hline
\end{tabular}

Questions number two was aimed at knowing the students' response of the timing English speaking use. From the data on table 2, it can be described that $73 \%$ of the students thought when studying; $14.3 \%$ when socializing; $4.8 \%$ at home; and $7.9 \%$ at office.

Table 3. Future use of English

\begin{tabular}{ccccccc}
\hline NO & QUESTIONS & & OPTIONS OF THE ANSWER & N & $\begin{array}{c}\text { STUDENTS' } \\
\text { ANSWER }\end{array}$ & $\%$ \\
& & & & & \\
\hline $\mathbf{3}$ & $\begin{array}{l}\text { In future I shall be } \\
\text { using English for } . .\end{array}$ & a. & Higher Education & 63 & 40 & 63.5 \\
& b. & Job/career & 63 & 16 & 25.4 \\
& c. & Socializing & 63 & 7 & 11.1 \\
& d. & At home & 63 & 0 & 0.0 \\
& e. & Others... & 63 & 0 & 0.0 \\
\hline
\end{tabular}

Questions number three was establish the future English speaking use of the students $63.5 \%$ of them thought that they will use it for higher education; $25.4 \%$ for seeking job or developing career; and 11.1 for socializing.

Table 4. Removal of speaking course from the curriculum 


\begin{tabular}{|c|c|c|c|c|c|c|}
\hline NO & QUESTIONS & & $\begin{array}{l}\text { OPTIONS OF THE } \\
\text { ANSWER }\end{array}$ & $\mathbf{N}$ & $\begin{array}{l}\text { STUDENTS' } \\
\text { ANSWER }\end{array}$ & $\%$ \\
\hline \multirow[t]{5}{*}{4} & Would you like speaking course to be taken & a. & Strongly disagree & 63 & 63 & 100 \\
\hline & $\begin{array}{l}\text { away from university curriculum because } \\
\text { you do not find the present syllabus and the }\end{array}$ & b. & Disagree & 63 & 0 & 0.0 \\
\hline & $\begin{array}{l}\text { way of classroom teaching helpful in } \\
\text { fulfilling your needs of English? }\end{array}$ & c. & Neutral & 63 & 0 & 0.0 \\
\hline & & d. & Agree & 63 & 0 & 0.0 \\
\hline & & e. & Strongly agree & 63 & 0 & 0.0 \\
\hline
\end{tabular}

Question number four was intended to get the students opinion about the place of English speaking in the curriculum structure of University. The data at table 4 shows that $100 \%$ of the students opposed the opinion of removing speaking from the curriculum event it was fulfill their needs.

Table 5. Students' level to academic performance

\begin{tabular}{cccccc}
\hline NO & QUESTIONS & OPTIONS OF THE ANSWER & N & $\begin{array}{c}\text { STUDENTS' } \\
\text { ANSWER }\end{array}$ & $\%$ \\
\hline $\mathbf{5}$ & $\begin{array}{l}\text { Do you think if a student's level } \\
\text { of English not good it can } \\
\text { have.... }\end{array}$ & a. A good effect on his & 63 & 8 & 12.7 \\
& b. $\quad \begin{array}{c}\text { A bademic performance } \\
\text { academic performance }\end{array}$ & 63 & 39 & 61.9 \\
& c. $\begin{array}{l}\text { No effect at all on his } \\
\text { performance }\end{array}$ & 63 & 15 & 23.8
\end{tabular}

Question number five is to find out the possible role of English in the present academic and future life of the students. The result shows that the students thought bad English proficiency determine a bad effect on academic performance $(61.9 \%)$. While the rest of them thought that it was not give any effect at all (23.8\%); and only $12.7 \%$ thought it has a good effect.

Table 6. Students' preferred learning styles 


\begin{tabular}{cllccc}
\hline NO & QUESTIONS & OPTIONS OF THE ANSWER & N & $\begin{array}{c}\text { STUDENTS' } \\
\text { ANSWER }\end{array}$ & \% \\
\hline $\mathbf{6}$ & $\begin{array}{l}\text { what kind of } \\
\text { Speaking class } \\
\text { do you like? }\end{array}$ & $\begin{array}{l}\text { a. a class with a lot of activities } \\
\text { b. Pair/group and project }\end{array}$ & 63 & 50 & 79.4 \\
& c. teaching only by the teacher and no activities \\
by the students & 63 & 03 & 0.0
\end{tabular}

Question no. six asked about the students' preference of speaking class activities. It can be seen from the table 5 that $79.4 \%$ of the students prefer to have a class with a lot of activities; only $20.6 \%$ of them like pair or group or project; and no one want learning with teacher centered.

Table 7. Preference for Doing Learning Activities

\begin{tabular}{lllccc}
\hline NO & QUESTIONS & \multicolumn{1}{c}{ OPTIONS OF THE ANSWER } & N & $\begin{array}{c}\text { STUDENTS' } \\
\text { ANSWER }\end{array}$ & \% \\
\hline 7 & $\begin{array}{c}\text { How do you prefer to do } \\
\text { learning activities }\end{array}$ & a. in the class & 63 & 22 & 34.9 \\
& $\quad \begin{array}{l}\text { b. Preference for working in pair or } \\
\text { groups }\end{array}$ & 63 & 41 & 65.1 \\
& $\quad \begin{array}{l}\text { c. preference for working alone } \\
\end{array}$ & 63 & 0 & 0.0
\end{tabular}

Questions number 7 investigated the student's preference of learning activities in the classroom. We can see that the data on table 7 noted $34.9 \%$ of the students prefer to do the activities in the class; $65.1 \%$ of them prefer for working in pair or groups.

Table 8. Pattern of preference for the role of teacher

\begin{tabular}{|c|c|c|c|c|c|}
\hline NO & QUESTIONS & OPTIONS OF THE ANSWER & $\mathbf{N}$ & $\begin{array}{l}\text { STUDENTS' } \\
\text { ANSWER }\end{array}$ & $\%$ \\
\hline
\end{tabular}




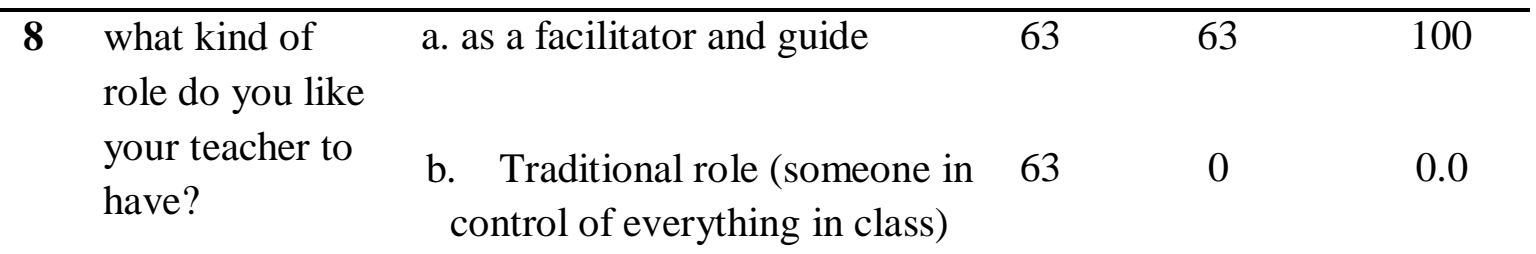

Question no eight focused to examine the students' preference of teacher's role. The result in table 8 above describe that $100 \%$ of the students assumed for the role of teacher as a facilitator and guide in the teaching learning activities.

\section{DISCUSSION}

As acknowledge that a Needs Analysis is gathering information process to reduce a gap among learners, teachers and learning materials (Pusphanathan, Haque). The result gives information about the target needs (Hutchinson \& Waters). It is what the learners need to do in the target situation (data on table 1 and 3). Majority of the students targeted of studying English speaking because they want to get success for future profession. And most of the students also want use English speaking for their higher education. A lecturer can consider those expectations of their future as learning objective in developing a syllabus of English speaking course.

The result has informed that the students' learning needs refer to what they need to do in order to learn. It is included in the data of table 2, 6,7,and 8. It was noted that In the learning processes most of the students want use English speaking together with their partners or groups. A lecturer can plan those noted as the main learning activities of speaking course syllabus development.

The data of needs analysis for the students' preference in learning speaking found as follows:

1. the students are studying English speaking because they want to get success for future profession.

2. the students want use English speaking when they are studying.

3. the students want use English speaking for their higher education. 
4. the students opposed the opinion of removing speaking from the curriculum event it was fulfill their needs.

5. the students level come together with his academic performance

6. the students want enjoy a speaking class with a lot of activities.

7. the students want do the learning activities together with their partners or groups.

8. the students assumed for the role of teacher as a facilitator and guide in the teaching learning activities.

Since the important of speaking to increase the students' competence to speak communicatively in the English education study program of FKIP UNRIKA, the lecturers are suggested to develop the speaking course syllabus based on the students' needs.

\section{REFERENCES}

Boroujeni \& Fard. (2013). A needs analysis of English for specific purposes (ESP) Course for adoption of communicative language teaching: ( A case of Iranian first-year students of educational administration. International Journal of Humanities and Social Science Invention ISSN (Online): 2319 - 7722, ISSN (Print): 2319 - 7714. Retrieved from: www.ijhssi.org Volume 2 Issue 6 || June. 2013\| PP.35-44.

Haque, Nurul. (2014). A Brief Study on Need Analysis. Express, an International Journal of Multi Disciplinary Research.ISSN: 2348 - 2052 , Vol. 1, Issue 1, January 2014. Retrieved from: at: www.express-journal.com

Jeclezeweski, Sebastian. (2016). Needs asnalysis, course design and evaluation of business English. School of Humanities. Department of English. University of Iceland

Manalullaili (2014). Teaching Speaking for Slow Learners. Proceedings of The $3{ }^{\text {rd }}$ UAD. TEFL International Conference 2014. ELT Materials Development in Asia and Beyond: Directions, Issues, and Challenges. September 17-18 September, Yogyakarta, Indonesia.

Otilia. (2015). Needs analysis in English for specific purposes. Annals of the Constantin Brâncuşi. University of Târgu Jiu, Economy Series, Issue 1, volume II/2015.

Solcova, Petra. (2011). Teaching speaking skills. Masaryk University Faculty of Arts Department of English and American Studies English Language and Literature and Teaching English Language and Literature for Secondary Schools 